Dunamis: Jurnal Teologi dan Pendidikan Kristiani

Volume 2, Nomor 2 (April 2018)

ISSN 2541-3937 (print), 2541-3945 (online)

http://www.sttintheos.ac.id/e-journal/index.php/dunamis

Submitted: 15 Desember 2017

Accepted: 19 Maret 2018

Published: 23 April 2018

\title{
Sebuah Analisis Terhadap Problematika Ajaran Restorasi Berkaitan Dengan Konsep Bumi Baru
}

\author{
Yudi Jatmiko \\ Bukit Batok Presbyterian Church, Singapore \\ yudi3036@yahoo.com
}

\begin{abstract}
The second coming of Christ is an event inalienable to mankind. In addition to declaring punishment for unbelievers, His second coming also fulfils the presence of a new heaven and earth in which the righteous will reign with Christ forever. Of this, the Bible records that "the heavens shall vanish with a great rumbling, and the elements of the world shall burn in the flames, and the earth and all that is therein shall pass away." But on the other hand, the view of restoration clearly teaches that the old heavens and the earth will not be totally destroyed, but renewed. Thus the problem arises: how could both of these things - the biblical concept of the new earth and the doctrine of restoration - be a harmonious truth? This paper seeks to explain and discuss the problematic teaching of the restoration in relation to the concept of the new earth. Through this paper the author hopes to elaborate the problematic of this topic clearly, especially regarding the alleged contradictions that exist. In addition, critical analysis is conducted to produce responsible solutions that contribute significantly to the study of eschatology, in which the authors believe that the teaching of restoration and the concept of the new earth is a harmonious and biblical truth.
\end{abstract}

Keywords: new earth concept; restoration; annihilation.

\begin{abstract}
Abstrak
Kedatangan Kristus kedua kali merupakan peristiwa yang tidak dapat dielakkan oleh umat manusia. Selain untuk menyatakan penghukuman bagi orang yang tidak percaya, kedatanganNya yang kedua juga menggenapi hadirnya langit dan bumi yang baru di mana orang benar akan memerintah bersama dengan Kristus selama-lamanya. Mengenai hal ini, Alkitab mencatat bahwa "langit akan lenyap dengan gemuruh yang dahsyat dan unsur-unsur dunia akan hangus dalam nyala api, dan bumi dan segala yang ada di atasnya akan hilang lenyap." Namun di sisi yang lain, pandangan restorasi dengan jelas mengajarkan bahwa langit dan bumi yang lama tidak akan dihancurkan secara total, melainkan diperbaharui. Dengan demikian timbul masalah: bagaimana mungkin kedua hal ini - konsep Alkitab tentang bumi yang baru dan ajaran restorasi - merupakan kebenaran yang harmonis? Tulisan ini berusaha memaparkan dan mendiskusikan problematika ajaran restorasi berkaitan dengan konsep bumi yang baru. Melalui tulisan ini penulis berharap dapat menguraikan problematika topik ini dengan jelas, khususnya mengenai dugaan kontradiksi yang ada. Selain itu, analisis kritis yang dilakukan diharapkan menghasilkan solusi yang bertanggungjawab sehingga memberikan kontribusi yang signifikan bagi studi eskatologi, dimana penulis meyakini bahwa ajaran restorasi dan konsep bumi baru merupakan kebenaran yang harmonis dan alkitabiah.
\end{abstract}


Kata Kunci: konsep bumi baru; restorasi; annihilasi.

\section{PENDAHULUAN}

Kedatangan Kristus kedua kali merupakan peristiwa yang tidak dapat dielakkan oleh umat manusia. Selain untuk menyatakan penghukuman bagi orang yang tidak percaya, kedatangan-Nya yang kedua juga menggenapi hadirnya langit dan bumi yang baru di mana orang benar akan memerintah bersama dengan Kristus selama-lamanya. Mengenai hal ini, Alkitab mencatat bahwa "langit akan lenyap dengan gemuruh yang dahsyat dan unsur-unsur dunia akan hangus dalam nyala api, dan bumi dan segala yang ada di atasnya akan hilang lenyap." (2 Pet. 3:10) Namun di sisi yang lain, pandangan restorasi dengan jelas mengajarkan bahwa langit dan bumi yang lama tidak akan dihancurkan secara total, melainkan diperbaharui. Dengan demikian timbul masalah. Mengenai kedua pandangan di atas, pandangan mana yang memiliki konsep Alkitabiah dan harmonis dalam interpretasi Alkitab? ${ }^{1}$

Tulisan ini berusaha memaparkan: pertama, konsep bumi yang baru dalam doktrin eskatologi; kedua, diskusi problematika ajaran restorasi berkaitan dengan konsep bumi yang baru. Batasan

\footnotetext{
${ }^{1}$ Anthony A. Hoekema, The Bible and the Future (Grand Rapids: Eerdmans, 1994), 279-280.
}

pembahasan adalah ada-tidaknya kontradiksi yang muncul atas dua poin ini. Dalam bagian ini akan dibahas pandangan yang mendukung dan menentang ajaran restorasi; ketiga, pembuktian eksegesis Alkitab terhadap lima bagian Alkitab mengenai problematika topik ini. Dengan mempertimbangkan keterbatasan ruang penulisan, lima bagian Alkitab yang akan dieksegesis adalah Matius 24:29; Kisah Para Rasul 3:21; Roma 8: 20-21; 2 Petrus 3:10; dan Wahyu 21:1.

Melalui tulisan ini penulis berharap dapat menguraikan problematika topik ini dengan jelas, khususnya mengenai dugaan kontradiksi yang ada. Selain itu, analisis kritis yang dilakukan diharapkan menghasilkan solusi yang bertanggungjawab sehingga memberikan kontribusi yang signifikan bagi studi eskatologi, dimana penulis meyakini bahwa ajaran restorasi dan konsep bumi baru merupakan kebenaran yang harmonis dan alkitabiah.

\section{METODE PENELITIAN}

Metode penelitian yang dipergunakan dalam menganalisis konsep Bumi Baru adalah metode eksegesis terhadap lima teks di dalam Perjanjian Baru, yaitu Matius 24:29, Kisah Para Rasul 
3:21, Roma 8:20-21, 2 Petrus 3:10, dan Wahyu 21:1.

\section{ANALISIS DAN HASIL}

\section{Tinjauan Sekilas Konsep Bumi Baru Dalam Doktrin Eskatologi}

Salah satu poin yang penting dalam doktrin eskatologi adalah konsep tentang bumi baru (new earth). ${ }^{2}$ Bumi yang baru juga sering disebut dengan istilah "langit dan bumi yang baru" (Yesaya 65:17; Wahyu 21:1). Dalam tulisan ini, frasa "bumi yang baru" mewakili konsep "langit dan bumi yang baru". Konsep ini merupakan hal yang diajarkan baik di dalam Perjanjian Lama maupun Perjanjian baru.

\section{Konsep Bumi Baru dalam Perjanjian} Lama

Di dalam Perjanjian Lama, konsep tentang bumi yang baru berkaitan erat dengan nubuatan dalam Perjanjian Lama tentang kondisi atau keadaan bumi yang lebih baik daripada sekarang. ${ }^{3}$ Nubuatan ini dimulai bahkan sejak kitab Kejadian. Kitab Kejadian menjelaskan bagaimana Allah menciptakan langit dan bumi yang pertama bagi manusia. ${ }^{4}$ Sayangnya, dosa

\footnotetext{
2 Ibid, 274.

${ }^{3}$ G. C. Berkouwer, Studies in Dogmatics: The Return of Christ (Grand Rapids: Eerdmans, 1975), 213.

${ }^{4}$ Bernike Sihombing, "Studi Penciptaan Menurut Kitab Kejadian 1:1-31," Kurios 1, no. 1 (February 12, 2018): 76-106, accessed March 5, 2018,
}

merusak segalanya, baik manusia mau pun bumi yang akhirnya mendapatkan kutukan. Namun pengharapan diberikan kepada manusia. Di dalam Kejadian 3:15 sebagai proto-evangelium - kepada ular dikatakan bahwa Allah "akan mengadakan permusuhan antara engkau dan perempuan ini, antara keturunanmu dan keturunannya; keturunannya akan meremukkan kepalamu, dan engkau akan meremukkan tumitnya." Ini merupakan janji penebusan Tuhan bagi umat-Nya. Namun Alkitab juga menjelaskan bahwa karena dosa manusia, bumi menanggung kutukan Tuhan. Mengenai kutukan terhadap bumi ini, Hoekema berpendapat bahwa kenyataan bumi telah dikutuk oleh karena dose manusia berdampak pada janji di mana kutuk yang ada di dalamnya akan dihapuskan sesuai dengan janji yang terdapat dalam Kejadian 3:15. ${ }^{5}$ Dengan demikian, janji tentang bumi baru telah tersirat dalam janji penebusan di Kejadian $3: 15$.

Selain itu, konsep tentang bumi yang baru juga diindikasikan melalui janji kepada Abraham bahwa keturunannya akan seperti "bintang di langit dan seperti pasir di tepi laut." (bd. Kej. 22:17) Di dalam Kejadian 15 dan 17, Alkitab dengan jelas mengatakan: "Pada hari itulah ${ }^{5}$ Hoekema, The Bible and the Future, 277. 
TUHAN mengadakan perjanjian dengan Abram serta berfirman: 'Kepada keturunanmulah Kuberikan negeri ini, mulai dari sungai Mesir sampai ke sungai yang besar itu, sungai Efrat' (Kej. 15:8). Inilah yang disebut sebagai tanah Kanaan, suatu negeri yang berlimpah susu dan madunya. Bagi Hoekema, janji mengenai tanah Kanaan ini merupakan bayangbayang dari janji akan "bumi yang baru itu". 6 Senada dengan hal ini, Berkouwer menegaskan bahwa tanah perjanjian dalam Perjanjian Lama sebenarnya bermakna lebih luas, yaitu bumi yang baru. ${ }^{7}$

Berbeda dengan kitab Kejadian, kitab Yesaya memiliki gambaran yang lebih eksplisit tentang konsep bumi yang baru ini. Yesaya 65:17-25 merupakan nubuatan yang jelas tentang hal ini. Perikop tersebut memaparkan janji pemulihan atas keadaan Yehuda. Dosa Yehuda menyebabkan kerajaan Selatan dibuang ke Babel. Walaupun demikian, Tuhan berjanji untuk memulihkan mereka jika mereka berbalik dan bertobat.

Yang menarik dalam perikop Yesaya 65:17-25 ialah bahwa nubuatan ini, sekalipun dalam konteksnya ditujukan kepada Yehuda dan Yerusalem (Yes. 65:18-19), juga merujuk kepada pemulihan bumi secara keseluruhan ketika Tuhan

\footnotetext{
${ }^{6}$ Ibid, 278.

${ }^{7}$ Berkouwer, Studies in Dogmatics: The Return of Christ, 213.
}

memulihkan keadaan bumi pada saat kedatangan Kristus yang kedua kali. Menurut Richard L. Pratt, nubuat berlapis ini tergenapi ketika pemulihan dari pembuangan pertama kali terjadi pada tahun 539 SM, digenapi dalam karya Kristus dan disempurnakan pada saat kedatangan-Nya. ${ }^{8}$ Pratt lebih jauh mengatakan bahwa kemuliaan dalam keselamatan dan kerajaan kebenaran dimulai sejak pemulihan dari pembuangan, menemukan maknanya dalam kedatangan Kristus yang pertama kalinya dan mencapai kesempurnaan dalam Kerajaaan Allah. $^{9}$ Menggarisbawahi hal ini, John Cavin menyimpulkan bahwa nabi dalam Perjanjian Lama berbicara mengenai pemulihan gereja yang menjadikannya sempurna apabila diperluas sampai kepada Kristus. ${ }^{10}$ Dengan demikian, nubuat dalam Yesaya 65:17-25 memiliki gema tentang konsep bumi yang baru, yang makin jelas terdengar sampai pada kedatangan Kristus kedua kali. ${ }^{11}$

G. C. Berkouwer di dalam Studies in Dogmatics: The Return of Christ mendedikasikan satu bab tersendiri untuk

\footnotetext{
${ }^{8}$ Richard L. Pratt Jr., ed., NIV Spirit of Reformation Study Bible (Grand Rapids: Zondervan, 2003), 1144.

${ }^{9}$ Ibid, 1159.

${ }^{10}$ Calvin's Commentaries: Commentary on Book of the Prophet Isaiah (Grand Rapids: Baker, 2005), 8398.

${ }^{11}$ William Hendriksen, More Than Conquerors (Grand Rapids: Baker, 2005), 195-201.
} 
membahas tentang bumi yang baru. $^{12}$ Mengenai perikop Yesaya 65:17-25, ia menyatakan bahwa gambaran tentang bumi yang baru adalah gambaran sukacita. ${ }^{13}$ Nabi Yesaya menyatakan bahwa di dalam bumi yang baru tersebut tidak akan ada "weeping and distress."14 Yang ada adalah umur yang panjang (ay.20), usaha membangun rumah (ay.21a), dan menanam kebun anggur (ay.21b). Ini merupakan gambaran metafora tentang kekekalan dan kesejahteraan di bumi yang baru. ${ }^{15}$

Relasi antara Allah dengan orangorang benar dalam bumi yang baru digambarkan dalam ayat 24: "Maka sebelum mereka memanggil, Aku sudah menjawabnya; ketika mereka sedang berbicara, Aku sudah mendengarkannya." Ini merupakan gambaran yang intim antara Allah dengan orang-orang yang benar. Gambaran ini berpulang kepada kondisi pertama ketika manusia dan bumi pertama kali diciptakan, di taman Eden. Alkitab mencatat bahwa pada waktu itu manusia mampu "mendengar bunyi langkah TUHAN Allah, yang berjalan-jalan dalam taman itu pada waktu hari sejuk" (Kej. 3:8). Sekalipun dalam bahasa metafora, penggambaran ini menunjukkan hubungan

\footnotetext{
${ }^{12}$ Berkouwer, Studies in Dogmatics: The Return of Christ, 211-234.

${ }^{13}$ Ibid, 212.

${ }^{14}$ Ibid

${ }^{15}$ Pratt Jr., NIV Spirit of Reformation Study Bible, 1188.
}

yang intim dan dekat sekali antara manusia dengan Allah pada waktu itu. Dengan demikian, Yesaya 65:24 adalah gaung ilahi yang menunjukkan relasi intim antara Allah dengan orang benar seperti ketika pertama kali Allah menciptakan mereka di taman Eden.

Selain itu, salah satu karakteristik dalam bumi yang baru sebagaimana diindikasikan dalam perikop ini adalah kekudusan dan kebenaran. Ayat 25 mengatakan dengan jelas bahwa "Tidak ada yang akan berbuat jahat atau yang berlaku busuk di segenap gunung-Ku yang kudus," firman TUHAN" (bd. 2 Pet. 3:13). Bumi yang baru akan dipenuhi oleh “pengenalan akan TUHAN" (Yes. 11:9). Inilah yang Berkouwer maksudkan ketika ia mengatakan bahwa langit dan bumi yang baru akan berisikan kedamaian dan kerukunan yang kontras dengan kerusakan yang ada di bumi saat ini. ${ }^{16}$ Kekudusan dan kebenaran merupakan kode etis yang utama dan dominan di dalam bumi yang baru karena Allah yang kudus hadir dan memerintah di sana.

Dengan demikian jelaslah sudah bahwa konsep tentang bumi yang baru merupakan poin penting yang diajarkan di dalam Perjanjian Lama. Hal tersebut berkaitan erat dengan nubuatan Perjanjian

\footnotetext{
${ }^{16}$ Berkouwer, Studies in Dogmatics: The Return of Christ, 212.
} 
Lama tentang bumi di mana Allah dan kebenaran-Nya memerintah atasnya. Benarlah apa yang Hoekema katakan bahwa untuk dapat memahami literatur nubuatan Perjanjian Lama adalah dengan mengingat-ingat doktrin bumi yang baru. ${ }^{17}$ Karenanya, pembaca ditolong untuk melihat nubuatan sebagai suatu pendeskripsian bimi yang baru. $^{18}$ Dan hanya dengan cara inilah, pembaca Perjanjian Lama dapat melihat teks dalam terang yang sebenarnya. ${ }^{19}$

\section{Konsep Bumi Baru dalam Perjanjian $\mathrm{Baru}^{20}$}

Di dalam Perjanjian Baru, konsep bumi yang baru semakin jelas baik dalam pengajaran Kristus, surat-surat para rasul, terutama Rasul Paulus dan Rasul Petrus, maupun Wahyu yang diterima oleh rasul Yohanes. Salah satu pengajaran Kristus yang paling terkenal mengenai bumi yang baru adalah sebagaimana yang termaktub dalam salah satu butir Khotbah di Bukit: "Berbahagialah orang yang lemah lembut, karena mereka akan memiliki bumi." Ini sekaligus menunjukkan konsistensi konsep bumi baru antara Perjanjian Lama dan Perjanjian Baru dalam pengajaran

\footnotetext{
${ }^{17}$ Hoekema, The Bible and the Future, 276.

${ }^{18}$ Ibid.

${ }^{19}$ Ibid.

${ }^{20}$ J. Reumann, Creation and New Creation: The Past, Present, and Future of God's Creative Activity (Minneapolis: Ausburg, 1973), 83-99.
}

Kristus. $^{21}$ "Bumi" dalam pengajaran Kristus ini tidak merujuk kepada bumi yang ada sekarang. Sebaliknya, dalam konsepsi pendengar mula-mula pada waktu itu yang notabene adalah orang Yahudi, "bumi" dalam bagian ini jelas mengingatkan mereka akan "tanah perjanjian," yaitu tanah Kanaan. Dengan mengutip Mazmur 37:11, Tuhan Yesus tidak semata-mata mengajak pendengarnya untuk terfokus pada bumi yang bersifat sementara di dunia ini. Sebaliknya, Ia memfokuskan pengajaran-Nya pada "bumi" yang akan datang, yaitu "bumi yang baru". Berkouwer menggarisbawahi hal ini dengan tepat sekali ketika mengatakan bahwa dalam khotbah di bukit Yesus mengatakan janji tentang negeri, yang bukan Kanaan, namun bumi yang baru. $^{22}$

Pengajaran yang sama juga diberikan oleh rasul Paulus dalam Roma 8:19-21. Di dalam konteks pasal 8 ini, Paulus menguraikan bahwa penebusan yang Kristus lakukan memungkinkan orang percaya untuk memiliki kehidupan yang bebas dari perbudakan dosa, yaitu kehidupan yang dipimpin oleh Roh. Di dalam hidup yang dikuasai oleh Roh ini, orang percaya menantikan janji pemuliaan dari Allah. Yang menarik dalam bagian ini

\footnotetext{
${ }^{21}$ Hoekema, The Bible and the Future, 281.

${ }^{22}$ Berkouwer, Studies in Dogmatics: The Return of Christ, 213.
} 
adalah bahwa beberapa Alkitab versi bahasa Inggris, misalnya versi The New International Version, English Standard Version, dan Revised Standard Version,

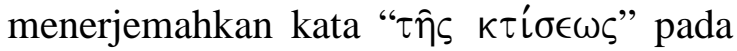
ayat 19 dengan lebih tepat, yaitu "the whole creation" atau "the creation". Ini menunjukkan bahwa bukan hanya orang percaya yang menantikan janji pemuliaan itu, tetapi "seluruh makhluk" atau "seluruh ciptaan." 23 Dengan sendirinya, Paulus mengindikasikan bahwa ketidaksempurnaan bumi yang sekarang ini, yang diakibatkan oleh dosa, seharusnya dipandang sebagai sarana kelahiran dunia yang lebih baik. $^{24}$ Ide ini jelas merujuk kepada bumi yang baru.

Sehati sepikir dengan rasul Paulus, Petrus juga mengajarkan hal yang sama dalam 2 Petrus 3:13. Ia mengatakan: “Tetapi sesuai dengan janji-Nya, kita menantikan langit yang baru dan bumi yang baru, di mana terdapat kebenaran." Bagi rasul Petrus, inilah yang menjadi dasar kekuatan untuk bertahan di tengahtengah penderitaan hidup sebagai orang kristen. $^{25}$ Pengharapan ini jugalah yang menjadi alasan yang hakiki mengapa

\footnotetext{
${ }^{23}$ Hoekema, The Bible and the Future, 282.

24 Ibid.

${ }^{25}$ Eliezer Lewis and Eliezer Lewis, "Studi Biblika Dan Teologis Surat 2 Petrus Pasal 3," Jurnal Jaffray 12, no. 2 (October 3, 2014): 317, accessed March 5, 2018, http://ojs.sttjaffray.ac.id/index.php/JJV71/article/vie $\mathrm{w} / 21$.
}

pembaca suratnya harus hidup suci dan saleh dalam dunia yang berdosa ini.

Akhirnya, di dalam Perjanjian Baru, konsep bumi yang baru dipaparkan dengan begitu jelas dalam wahyu Tuhan Yesus kepada Yohanes. Dalam Wahyu 21:1 Yohanes mengatakan: "Lalu aku melihat langit yang baru dan bumi yang baru, sebab langit yang pertama dan bumi yang pertama telah berlalu, dan lautpun tidak ada lagi." Begitu indahnya bumi yang baru itu sehingga Yohanes mengatakan: "Dan aku melihat kota yang kudus, Yerusalem yang baru, turun dari sorga, dari Allah, yang berhias bagaikan pengantin perempuan yang berdandan untuk suaminya. Lalu aku mendengar suara yang nyaring dari takhta itu berkata: "Lihatlah, kemah Allah ada di tengahtengah manusia dan Ia akan diam bersamasama dengan mereka. Mereka akan menjadi umat-Nya dan Ia akan menjadi Allah mereka. Dan Ia akan menghapus segala air mata dari mata mereka, dan maut tidak akan ada lagi; tidak akan ada lagi perkabungan, atau ratap tangis, atau dukacita, sebab segala sesuatu yang lama itu telah berlalu" (Why. 21:2-4). Hoekema menyimpulkan bagian ini dengan baik sekali ketika mengatakan bahwa melalui ayat tersebut dapat diketahui bahwa gereja yang dimuliakan akan hidup dalam 
kekekalan di bumi yang baru. $^{26}$ Jika demikian halnya, jelaslah sudah bahwa bumi yang baru merupakan konsep yang diajarkan dengan jelas baik di dalam Perjanjian Lama maupun Perjanjian Baru. Konsep ini masih tampak samar dalam Perjanjian Lama namun makin jelas dan memuncak di dalam pengajaran Perjanjian Baru.

\section{Problematika Ajaran Restorasi}

\section{Berkaitan Dengan Konsep Bumi Baru}

Konsep bumi baru - betapapun jelasnya diajarkan di dalam Alkitab - tetap memunculkan problematika. Masalah ini muncul berkaitan dengan natur bumi yang baru tersebut. Hoekema merumuskan hal ini dengan tepat bahwa pertanyaan yang harus dihadapi adalah apakah bumi yang sama sekali baru ataukah pembaharuan dari bumi yang sudah ada saat ini. ${ }^{27}$ Mengenai hal ini, ajaran restorasi dengan jelas menyatakan bahwa bumi yang lama tidak akan dihancurkan secara total, melainkan diperbaharui. ${ }^{28}$ Pada bagian ini akan dibahas pandangan yang menentang dan mendukung ajaran restorasi.

\section{Pandangan Yang Menentang Ajaran}

\section{Restorasi}

\footnotetext{
${ }^{26}$ Hoekema, The Bible and the Future, 285.

${ }^{27}$ Ibid, 279.

${ }^{28}$ Simon J. Kistemaker, Tafsiran Kitab Wahyu (Surabaya: Momentum, 2009), 595-560.
}

Pandangan yang menentang ajaran restorasi ini sering disebut annihilation (kehancuran total). ${ }^{29}$ Di dalam konsepsi annihilation, menjelang kedatangan Kristus yang kedua, langit dan bumi yang sekarang ada akan dihancurkan secara total sehingga orang percaya dapat hidup di dalam bumi yang baru, yang sama sekali berbeda dengan bumi yang ada sekarang. Karenanya, bumi yang baru bukanlah kelanjutan (continuity) dari bumi yang ada sekarang. Sebaliknya, bumi yang baru akan diciptakan oleh Allah dengan prinsip creatio ex nihilo seperti bumi yang pertama dahulu. ${ }^{30}$ Paling tidak, pandangan annihilation mendasarkan argumen ini pada dua alasan: natur bumi sekarang yang berdosa dan pembuktian dari ayat firman Tuhan.

Di dalam konsepsi annihilation, "creation is evil, and the Lord must completely destroy this earth." ${ }^{31}$ Ini jelas sekali dalam kutukan yang Tuhan berikan kepada ciptaan oleh karena dosa manusia yang pertama kali. Dan sejak saat itu, bumi yang penuh dosa menjadi semakin rusak dan jelas tidak ada kebaikan yang dapat diharapkan dari bumi yang sekarang ini. Pandangan yang sama juga dinyatakan

\footnotetext{
${ }^{29}$ Hoekema, The Bible and the Future, 279-280.

${ }^{30}$ Ibid.

${ }^{31}$ Williem V. Gemeran, The Progress of Redemption: The Story of Salvation from Creation to the New Jerusalem (Grand Rapids: Zondervan, 1988), 452.
} 
oleh Berkouwer bahwa tidak ada harapan masa depan dari bumi yang telah diperbudak oleh kejahatan. $^{32}$ Dengan mempertimbangkan dosa dan kerusakan yang begitu merajalela di bumi ini, jelas bumi yang baru haruslah sesuatu yang sepenuhnya berbeda dari bumi ini, bukan kelanjutannya.

Alasan yang kedua yang dipegang oleh pandangan ini adalah bahwa Alkitab mengajarkan annihilation. Biasanya, dua ayat yang dipakai menjadi dasar pandangan ini adalah Matius 24:29 dan 2 Petrus 3:10 dan 13. Menurut pandangan ini, di dalam Matius 24:29 Tuhan Yesus menyatakan bahwa "matahari akan menjadi gelap dan bulan tidak bercahaya dan bintang-bintang akan berjatuhan dari langit dan kuasa-kuasa langit akan goncang" menjelang kedatangan-Nya yang kedua. Dengan kata lain, sebelum Ia datang dalam kemuliaan-Nya, langit dan bumi akan dihancurkan secara total. Kesimpulan ini juga didukung oleh pernyataan Petrus dalam 2 Petrus 3:10 dan 13. Di sana dikatakan bahwa "hari Tuhan akan tiba seperti pencuri. Pada hari itu langit akan lenyap dengan gemuruh yang dahsyat dan unsur-unsur dunia akan hangus dalam nyala api, dan bumi dan segala yang ada di atasnya akan hilang

\footnotetext{
${ }^{32}$ Berkouwer, Studies in Dogmatics: The Return of Christ, 219.
}

lenyap" (2 Petrus 3:10). Memperkuat pandangan ini, dalam ayat 13, frasa

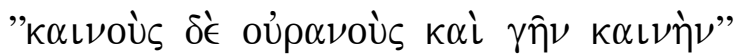
(langit dan bumi yang baru) merujuk kepada akar kata yang sama yaitu "к $\alpha \iota \nu o ́ \varsigma "$ yang berarti baru. Menurut pandangan annihilation, kata "к $\alpha \iota \nu o ́ \varsigma "$ dalam ayat ini jelas menunjukkan substansi bumi yang baru dan karenanya tidak mungkin terjadi restorasi terhadap bumi yang ada sekarang. ${ }^{33}$

Pandangan Yang Mendukung Ajaran Restorasi

$\begin{array}{rrr}\text { Berbanding } & \text { terbalik } & \text { dengan } \\ \text { annihilation, pandangan } & \text { restorasi }\end{array}$
menyatakan dengan tegas bahwa sekalipun bumi yang ada sekarang telah dirusak begitu rupa oleh dosa, namun penebusan Kristus memberi dampak pemulihan global yang memuncak pada pembaharuan akhir ciptaan pada kedatangan-Nya yang kedua kali. Gemeran menyatakan bahwa penebusan bukanlah pembebasan dari material bumi namun pembaharuan dan pemurniaannya. ${ }^{34}$ Dengan berpijak pada penebusan Kristus, yang memulihkan bukan hanya orang percaya tapi juga ciptaan dari kutukan Allah, pandangan ini menantikan bumi baru yang diperbaharui

\footnotetext{
${ }^{33}$ Hoekema, The Bible and the Future, 280.

${ }^{34}$ Gemeran, The Progress of Redemption: The Story of Salvation from Creation to the New Jerusalem, 451.
} 
(direstorasi) atau disucikan oleh Kristus. ${ }^{35}$ Selain argumen penebusan Kristus yang berdampak kosmik, pandangan restorasi juga memiliki dasar pijak biblika dari ayatayat firman Tuhan. Argumen biblika ini akan diuraikan dengan lebih rinci pada bagian berikutnya.

Terlepas dari dua argumen di atas, Hoekema mengusulkan empat alasan mengapa pandangan annihilation harus ditolak. ${ }^{36}$ Pertama, membantah argumen annihilation tentang konsep kata "к $\alpha \iota \nu o ́ s "$, Hoekema menyatakan bahwa kata

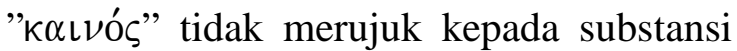
(sebagaimana yang dipahami oleh pandangan annihilation), melainkan kepada natur dan kualitas. ${ }^{37}$ Konsekuensi logisnya adalah bahwa bumi yang baru itu - betapapun mulianya setelah diperbaharui - merupakan "continuity with the present one."38 Kedua, Hoekema menyatakan bahwa dalam Roma 8, seluruh ciptaan menantikan untuk diperbaharui, bukan dihancurkan secara total. ${ }^{39}$ Ketiga, analogi antara bumi yang baru dengan kebangkitan tubuh. Sebagaimana tubuh yang dibangkitkan adalah memiliki nuansa "continuity" dari tubuh yang sekarang, begitu juga dengan bumi yang baru adalah "continuity" dari bumi yang sekarang. ${ }^{40}$ Keempat, jika konsep annihilation adalah benar maka iblis lebih unggul dari Allah. Ini disebabkan karena Allah tidak mampu merestorasi bumi yang sudah dirusak oleh iblis, selain menghancurkannya secara total. Hal ini jelas tidak mungkin demikian. Karenanya, Hoekema menolak konsep penghancuran total. ${ }^{41}$

Dengan demikian, kesimpulan sementara yang dapat ditarik adalah bahwa dengan mempertimbangkan dampak kosmik penebusan Kristus, tidak ada alasan bagi Allah untuk tidak mampu dan mau memperbaharui dunia yang penuh dosa ini. Sebaliknya, Ia memang berniat dan berencana untuk merestorasi serta memurnikan bumi ini menjadi bumi yang baru sebagai habitat orang-orang benar di mana kekudusan dan kebenaran memerintah selama-lamanya. Karenanya, tidak ada kontradiksi antara pandangan restorasi dengan kebenaran Alkitab. Walaupun demikian, studi mendalam terhadap bagian-bagian Alkitab perlu dilakukan untuk mendapatkan pembuktian eksegesis dan kesimpulan yang utuh atas butir kebenaran ini.

\footnotetext{
${ }^{35}$ Ibid, 452.

${ }^{36}$ Hoekema, The Bible and the Future, 280-281.

${ }^{37}$ Ibid, 280.

${ }^{38}$ Ibid.

${ }^{39}$ Ibid.
}

$$
\begin{aligned}
& { }^{40} \text { Ibid. } \\
& { }^{41} \text { Ibid. }
\end{aligned}
$$

97 Copyright $@$ 2018, Dunamis, ISSN 2541-3937 (print), 2541-3945 (online) 
Pembuktian Eksegesis Terhadap Lima Bagian Alkitab Mengenai Problematika Ajaran Restorasi

Kesulitan di antara kedua pandangan ini - annihilation dan restoration - bukan hal yang mudah untuk dipecahkan. Keduanya sama-sama memiliki argumen yang kuat. Karenanya, penulis merasa perlu untuk melakukan studi eksegesis terhadap bagian-bagian Alkitab yang sering diperdebatkan berkaitan dengan kedua pandangan ini. Kelima bagian Alkitab tersebut adalah Matius 24:29; Kisah Para Rasul 3:21; Roma 8: 20-21; 2 Petrus 3:10; dan Wahyu 21:1.

\section{Matius 24:29}

Konteks Matius 24 adalah berbicara tentang tanda yang menyertai kedatangan Anak Manusia. Ayat 29 sering disimpulkan bahwa kehancuran total bumi akan mendahului parousia (kedatangan Kristus yang kedua kalinya). Mengenai hal ini, R. T. France, seorang sarjana Perjanjian Baru mengatakan bahwa ayat 29 merupakan jawaban dengan bahasa simbolis bagi pertanyaan pertama para murid. $^{42}$ Senada dengan France, Craig L. Bloomberg menjelaskan bahwa Yesus

\footnotetext{
${ }^{42}$ R. T. France, The New International Commentary on the New Testament: The Gospel of Matthew (Grand Rapids: Eerdmans, 2007), 923.
}

menggambarkan kedatangan-Nya kembali dengan menggunakan bahasa gambaran apokaliptis dan bukan untuk dimaknai secara literal. ${ }^{43}$ Sekalipun dari pendekatan budaya-historis hal ini dapat dipertimbangkan, satu poin penting yang harus diperhatikan adalah bahwa tidak ada indikasi dalam perikop ini bahwa Tuhan Yesus memaksudkan ayat 29 itu harus ditafsirkan sebagai sebuah metafora. Sebaliknya, kedatangan Kristus kedua kali akan menunggang balikkan segala kuasa di surga dan di bumi untuk tunduk kepadaNya karena Ia adalah pemegang kekuasaan tertinggi. $^{44}$ Melalui hal ini dapat disimpulkan bahwa memang akan ada kehancuran dahsyat menjelang kedatangan Kristus kedua. Walaupun demikian, satu poin penting perlu digarisbawahi, dalam ayat ini ataupun konteks perikopnya, tidak dikatakan kehancuran total, hanya kehancuran yang dahsyat. Dengan demikian, ayat ini tidak dapat menjadi dasar bagi konsep annihilation. ${ }^{45}$

\section{Kisah Para Rasul 3:21}

Bagian yang mendukung pandangan restorasi tersirat di dalam kata

\footnotetext{
${ }^{43}$ Craig L Bloomberg, The New American Commentary: Matthew (Nashville: Broadman, 1992), 362.

${ }^{44}$ Leon Morris, The Pillar New Testament Commentary: The Gospel According to Matthew (Grand Rapids: Eerdmans, 1992), 609-610.

${ }^{45}$ Jr. MacArthur, J., The MacArthur New Testament Commentary: Matthew 24-28 (Chicago: Moody, 1989), 51
} 


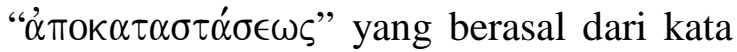

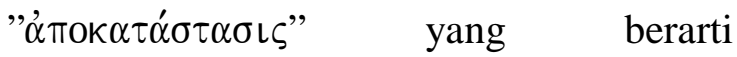
"pemulihan" atau "restoration". Di dalam bagian ini, Petrus menegaskan bahwa Kristus harus tinggal di surga sampai waktu pemulihan segala sesuatu tiba. Mengenai hal ini, F. F. Bruce mengatakan bahwa puncak zaman baru adalah disertai dengan pembaharuan bagi seluruh alam. ${ }^{46}$ Pada bagian ini jelas sekali bahwa Petrus merefleksikan pengharapan jemaat mulamula bahwa Kristus akan memerintah atas Kerajaan Israel yang dipulihkan. ${ }^{47}$ Ayat ini jelas sekali mendukung pandangan restorasi alih-alih pandangan annihilation. Dengan kata lain, menjelang kedatanganNya yang kedua, yang terjadi bukanlah kehancuran total dari bumi, melainkan restorasi. ${ }^{48}$

\section{Roma 8: 20-21}

Bagian ini erat kaitannya dengan dampak kosmik penebusan Kristus, yaitu di mana kutukan awal itu dicabut dan bumi direstorasi menjadi bumi baru sebagai tempat umat tebusan Allah. Mendukung pandangan ini, James D. G. Dunn mengatakan bahwa dalam pemikiran

\footnotetext{
${ }^{46}$ F. F. Bruce, The New International Commentary on the New Testament: The Book of the Acts (Grand Rapids: Eerdmans, 1981), 91.

${ }^{47}$ Paul W. Walaskay, Westminster Bible Companion: Acts (Louisville: Westminster John Knox, 1989), 54.

${ }^{48}$ Jr. MacArthur, J., The MacArthur New Testament Commentary: Acts 1-12 (Chicago: Moody, 1994), 121.
}

Paulus ciptaan harus mengalami penebusan agar manusia yang telah ditebus dapat hidup dalam lingkungan yang tepat. ${ }^{49}$ Menggarisbawahi hal ini, Edwards mengatakan bahwa jika kutukan bagi ciptaan disebabkan oleh Adam, maka penebusan akan bergantung pada Kristus. ${ }^{50}$ Dan dengan berpijak pada penebusan Kristus, Erdwards menyimpulkan bahwa jika kebangkitan Kristus akan memberikan tubuh rohani demikian juga dengan pembaruan dari tubuh ciptaan. ${ }^{51}$ Sekali lagi bagian Alkitab ini mendukung pandangan restorasi.

\section{Petrus 3:10}

Ayat ini tampaknya merupakan ayat yang paling kuat mendukung pandangan annihilation. Namun satu hal yang perlu dicermati dengan teliti ialah bahwa pada saat hari Tuhan itu tiba, yang dihancurkan oleh api adalah unsur-unsur bumi, bukan bumi itu sendiri. ${ }^{52}$ Selain itu, api yang dimaksudkan dalam ayat itu bukan sematamata untuk menghancurkan, tapi untuk memurnikan. Ini erat kaitannya dengan pemulihan dari kutukan awal yang Allah berikan kepada bumi. Matthew Henry

\footnotetext{
49 James D. G. Dunn, Word Biblical Commentary: Romans 1-8 (Dallas: Word, 1988), 471.

${ }^{50}$ James R. Edwards, New International Biblical Commentary: Romans (Peabody: Hendrickson, 1992), 213.

${ }^{51}$ Ibid, 215

${ }^{52}$ Peter H. Davis, The Pillar New Testament Commentary: The Letter of 2Peter and Jude (Grand Rapids: Eerdmans, 2006), 283.
} 
merumuskan hal ini dengan indah bahwa semuanya akan dimurnika melalui api. ${ }^{53}$ Jika demikian, apakah penghancuran unsur-unsur bumi ini adalah total annihilation? Mengenai hal ini, pendapat Moo layak untuk dipertimbangkan. Ia mengatakan bahwa Petrus tidak berbicara tentang penghancuran total bumi namun tentang pemurniannya. ${ }^{54}$ Bandingkan juga dengan pandangan Wolter mengenai penafsiran surat Petrus ini. ${ }^{55}$ Akhirnya, Norman Hillyer menyimpulkan bahwa pada hari di mana ada bencana dalam skala besar adalah untuk tujuan pemugaran langit dan bumi. $^{56}$ Dengan demikian, jelaslah sudah bahwa bagian ini pun tidak serta-merta mendukung pandangan annihilation. Sebaliknya, ulasan eksegesis dari para pakar Perjanjian Baru menunjukkan bahwa bagian ini, yang tampaknya mendukung ajaran annihilation, sebaliknya lebih mendekati pandangan restorasi bumi baru.

\section{Wahyu 21:1}

Dalam ayat ini dikatakan bahwa "langit yang pertama dan bumi yang

\footnotetext{
${ }^{53}$ M. Henry, Commentary on the Whole Bible (Grand Rapids: Zondervan, 1980), 1953.

${ }^{54}$ Douglas J. Moo, "Nature in the New Creation: New Testament Eschatology and the Environment," Journal of the Evangelical Theological Society 49, no. 3 (2006): 449-488.

${ }^{55}$ Al. Wolters, "Worldview and Textual Criticism in 2 Peter 3:10," The Westminster Theological Journal 49, no. 2 (1987): 405-413.

${ }^{56}$ N. Hillyer, New International Biblical Commentary: 1 and 2Peter, Jude (Peabody: Hendrickson, 1992), 217.
}

pertama telah berlalu." Pembacaan sekilas menunjukkan bahwa bumi yang baru tidak mungkin kelanjutan dari bumi yang lama karena Alkitab dengan jelas mengajarkan bahwa bumi yang lama telah berlalu. Namun penting untuk diperhatikan dalam bagian ini ialah bahwa yang berlalu bukanlah substansinya, melainkan kualitasnya. $^{57}$ Ini berarti bahwa kualitas bumi yang lama (yang penuh dosa) akan berlalu dan digantikan dengan kualitas bumi yang baru (yang penuh dengan kekudusan). Namun, esensi bumi itu sendiri - baik yang lama maupun yang baru - tetap sama, yaitu bumi yang pernah Allah ciptakan. Bedanya, sekarang bumi itu dikuasai dosa, tapi nanti bumi itu akan disucikan oleh api. ${ }^{58}$ Dengan demikian, bumi itu sendiri pada esensinya direstorasi oleh Allah, bukan dihancurkan total. Penting untuk diperhatikan, restorasi tidak meniadakan penghancuran. Namun yang dihancurkan bukanlah bumi itu sendiri, melainkan "unsur-unsurnya" atau tatanannya. ${ }^{59}$ Hendriksen menyimpulkan bahwa yang dimaksudkan oleh kitab Wahyu adalah pemurnian. ${ }^{60}$

Berdasarkan penelaahan di atas, tampak jelas bahwa sekalipun terjadi

\footnotetext{
${ }^{57}$ G. K. Beale, The New International Greek Testament Commentary: The Book of Revelation (Grand Rapids: Eerdmans, 1999), 1040.

${ }^{58}$ Ibid.

${ }^{59}$ Kistemaker, Tafsiran Kitab Wahyu, 595.

${ }^{60}$ Hendriksen, More Than Conquerors, 196.
} 
kehancuran bumi pada zaman akhir, yang dimaksud bukanlah annihilation melainkan purification. Dengan demikian, dapat disimpulkan bahwa tidak ada kontradiksi antara konsep Alkitab tentang bumi yang baru dan ajaran restorasi. Keduanya merupakan kebenaran yang harmonis.

\section{KESIMPULAN}

Berdasarkan analisis kritis yang dilakukan pada bagian kedua dan ketiga, penulis melihat bahwa ajaran bumi yang baru dan restorasi adalah hal yang diajarkan oleh Alkitab. Keduanya merupakan butir kebenaran yang signifikan bagi studi eskatologi yang sehat. Selain itu, studi mendalam atas lima bagian Alkitab pada bagian keempat menunjukkan beberapa hal: pertama, adanya kontinuitas secara substansi antara bumi yang lama dengan bumi yang baru; kedua, kehancuran yang terjadi pada saat kedatangan Kristus kedua kali tidak bersifat total annihilation bagi bumi. Sebaliknya, kehancuran ini bersifat purification karena bertujuan memurnikan bumi dari kutukan dosa melalui dampak kosmik penebusan Kristus; ketiga, beberapa bagian Alkitab yang ditelaah pada bagian keempat sendiri memberikan dukungan biblika bagi pandangan restorasi; keempat, para pakar - baik biblika maupun sistematika - lebih mendukung pandangan restorasi alih-alih annihilation. Dengan demikian dapat disimpulkan bahwa tidak ada kontradiksi antara kebenaran Alkitab tentang bumi yang baru dengan pandangan restorasi. Keduanya merupakan kebenaran yang harmonis dan diajarkan oleh Alkitab.

Karena Alkitab mengajarkan bahwa bumi yang ada sekarang akan direstorasi oleh Allah, maka konsep ini memiliki implikasi praktis. Orang percaya didorong untuk melihat bumi ini sebagai milik Allah, bukan milik iblis. Sekalipun dosa dan kecemaran begitu mewarnai bumi yang ada sekarang, orang percaya memiliki pengharapan bahwa suatu saat kekudusan dan kebenaran akan memerintah bumi ini dengan sempurna dan di hadapan Allah. ${ }^{61}$ Puji Tuhan untuk janji tentang bumi baru yang direstorasi ini.

\section{DAFTAR KEPUSTAKAAN}

Beale, G. K. The New International Greek Testament Commentary: The Book of Revelation. Grand Rapids: Eerdmans, 1999.

Berkouwer, G. C. Studies in Dogmatics: The Return of Christ. Grand Rapids: Eerdmans, 1975.

Bloomberg, Craig L. The New American Commentary: Matthew. Nashville: Broadman, 1992.

Bruce, F. F. The New International Commentary on the New Testament: The Book of the Acts. Grand Rapids: Eerdmans, 1981.

\footnotetext{
${ }^{61}$ Hoekema, The Bible and the Future, 287.
} 
Davis, Peter H. The Pillar New Testament Commentary: The Letter of 2Peter and Jude. Grand Rapids: Eerdmans, 2006.

Dunn, James D. G. Word Biblical Commentary: Romans 1-8. Dallas: Word, 1988.

Edwards, James R. New International Biblical Commentary: Romans. Peabody: Hendrickson, 1992.

France, R. T. The New International Commentary on the New Testament: The Gospel of Matthew. Grand Rapids: Eerdmans, 2007.

Gemeran, Williem V. The Progress of Redemption: The Story of Salvation from Creation to the New Jerusalem. Grand Rapids: Zondervan, 1988.

Hendriksen, William. More Than Conquerors. Grand Rapids: Baker, 2005.

Henry, M. Commentary on the Whole Bible. Grand Rapids: Zondervan, 1980.

Hillyer, N. New International Biblical Commentary: 1 and 2Peter, Jude. Peabody: Hendrickson, 1992.

Hoekema, Anthony A. The Bible and the Future. Grand Rapids: Eerdmans, 1994.

Kistemaker, Simon J. Tafsiran Kitab Wahyu. Surabaya: Momentum, 2009.

Lewis, Eliezer, and Eliezer Lewis. "Studi Biblika Dan Teologis Surat 2 Petrus Pasal 3." Jurnal Jaffray 12, no. 2 (October 3, 2014): 317. Accessed March 5, 2018. http://ojs.sttjaffray.ac.id/index.php/JJ V71/article/view/21.
MacArthur, J., Jr. The MacArthur New Testament Commentary: Acts 1-12. Chicago: Moody, 1994.
- The MacArthur New Testament Commentary: Matthew 24-28. Chicago: Moody, 1989.

Moo, Douglas J. "Nature in the New Creation: New Testament Eschatology and the Environment." Journal of the Evangelical Theological Society 49, no. 3 (2006): 449-488.

Morris, Leon. The Pillar New Testament Commentary: The Gospel According to Matthew. Grand Rapids: Eerdmans, 1992.

Pratt Jr., Richard L., ed. NIV Spirit of Reformation Study Bible. Grand Rapids: Zondervan, 2003.

Reumann, J. Creation and New Creation: The Past, Present, and Future of God's Creative Activity. Minneapolis: Ausburg, 1973.

Sihombing, Bernike. "Studi Penciptaan Menurut Kitab Kejadian 1:1-31." Kurios 1, no. 1 (February 12, 2018): 76-106. Accessed March 5, 2018. http://sttpb.ac.id/ejournal/index.php/kurios/article/view/ $15 / 39$.

Walaskay, Paul W. Westminster Bible Companion: Acts. Louisville: Westminster John Knox, 1989.

Wolters, Al. "Worldview and Textual Criticism in 2 Peter 3:10." The Westminster Theological Journal 49, no. 2 (1987): 405-413.

Calvin's Commentaries: Commentary on Book of the Prophet Isaiah. Grand Rapids: Baker, 2005. 